\title{
LORD DEVLIN AND THE ENFORCEMENT OF MORALS
}

\section{RONALD DWORKIN*}

No doubt most Americans and Englishmen think that homosexuality, prostitution, and the publication of pornography are immoral. What part should this fact play in the decision whether to make them criminal? This is a tangled question, full of issues with roots in philosophical and sociological controversy. It is a question lawyers must face, however, and two recent and controversial events-publication of the Wolfenden Report in England, 1 followed by a public debate on prostitution and homosexuality, and a trio of obscenity decisions in the United States Supreme Court ${ }^{2}$-press it upon us.

Several positions are available, each with its own set of difficulties. Shall we say that public condemnation is sufficient, in and of itself, to justify making an act a crime? This seems inconsistent with our traditions of individual liberty, and our knowledge that the morals of even the largest mob cannot come warranted for truth. If public condemnation is not sufficient, what more is needed? Must there be some demonstration of present harm to particular persons directly affected by the practice in question? Or is it sufficient to show some effect on social customs and institutions which alters the social environment, and thus affects all members of society indirectly? If the latter, must it also be demonstrated that these social changes threaten long-term harm of some standard sort, like an increase in crime or a decrease in productivity? Or would it be enough to show that the vast bulk of the present community would deplore the change? If so, does the requirement of harm add much to the bare requirement of public condemnation?

In 1958 Lord Devlin delivered the second Maccabaean Lecture to the British Academy. He called his lecture "The Enforcement of Morals," and devoted it to these issues of principle. ${ }^{3}$ His conclusions

- Professor of Law, Yale University.

1. Report of the Committee on Homosexual Offenses and Prostitution, CMD. No. 247 (1957).

2. Memoirs v. Massachusetts (Fanny Hill), 383 U.S. 413 (1966), Ginzburg v. United States, 383 U.S. 463 (1966), Mishkin v. New York, 383 U.S. 502 (1966).

3. Devin, The Enforcement of Morals (Oxford University Press 1959). Reprinted in Devilin, The Enforcement of Morals (Oxford University Press 1965). [The lattcr is hereinafter cited as DEvLrN.] 
he summarized in these remarks about the practice of homosexuality: "We should ask ourselves in the first instance whether, looking at it calmly and dispassionately, we regard it as a vice so abominable that its mere presence is an offense. If that is the genuine feeling of the society in which we live, I do not see how society can be denied the right to eradicate it."4

The lecture, and in particular this hypothetical position on punishing homosexuals, provoked a tide of rebuttal that spilled over from academic journals into the radio and the almost-popular press. 5 Lord Devlin has now republished the Maccabaean Lecture, together with six further essays developing and defending the views there expressed, a preface to the whole, and some important new footnotes to the original lecture. ${ }^{\circ}$

American lawyers ought to attend to Lord Devlin's arguments. His conclusions will not be popular, although the swaggering insensitivity some of his critics found disappears with careful reading. Popular or not, we have no right to disregard them until we are satisfied that his arguments can be met. One of these arguments-the second of the two I shall discuss-has the considerable merit of focusing our attention on the connection between democratic theory and the enforcement of morals. It provokes us to consider, more closely than we have, the crucial concept upon which this connection depends-the concept of a public morality.

\section{LoRd Devin's Disenchantarent}

The preface to the new book contains a revealing account of how Lord Devlin came to his controversial opinions. When he was invited to prepare his Maccabaean Lecture the celebrated Wolfenden Committee had recently published its recommendation that homosexual practices in private between consenting adults no longer be criminal. He had read with complete approval the Committee's expression of the proper division between crime and sin:

In this field, its [the law's] function, as we see it, is to preserve public order and decency, to protect the citizen from what is offensive or injurious, and to provide sufficient safeguards against exploitation and corruption of others . . . . It is not, in our view,

4. Devurn 17. This position was carefully stated as hypothetical. Apparently Lord Devlin does not now think that the condition is met, because he has publically urged modification of the laws on homosexuality since the book's publication.

5. Lord Devlin includes references to these comments in a bibliography. DEvis xiii.

6. Devin. 
the function of the law to intervene in the private lives of citizens, or to seek to enforce any particular pattern of behavior, further than is necessary to carry out the purposes which we have outlined ....

$[T]$ here must remain a realm of private morality and immorality which is, in brief and crude terms, not the law's business.?

Lord Devlin believed that these ideals, which he recognized as derived from the teachings of Jeremy Bentham and John Stuart Mill, were unquestionable. He decided to devote his lecture to a painstaking consideration of what further changes, beyond the changes in the crime of homosexuality that the Committee recommended, would be necessary to make the criminal law of England conform to them. But study, in his words, "destroyed instead of confirming the simple faith in which I had begun my task" and he ended in the conviction that these ideals were not only questionable, but wrong.

The fact of his disenchantment is clear, but the extent of his disenchantment is not. He seems sometimes to be arguing the exact converse of the Committee's position, namely that society has a right to punish conduct of which its members strongly disapprove, even though that conduct has no effects which can be deemed injurious to others, on the ground that the state has a role to play as moral tutor and the criminal law is its proper tutorial technique. Those readers who take this to be his position are puzzled by the fact that distinguished philosophers and lawyers have concerned themselves to reply, for this seems a position that can safely be regarded as eccentric. In fact he is arguing not this position, but positions which are more complex and neither so eccentric nor so flatly at odds with the Wolfenden ideals. They are nowhere summarized in any crisp form (indeed the statement on homosexuality I have already quoted is as good a summary as he gives) but must be taken from the intricate arguments he develops.

There are two chief arguments. The first is set out in structured form in the Maccabaean Lecture. It argues from society's right to protect its own existence. The second, a quite different and much more important argument, develops in disjointed form through various essays. It argues from the majority's right to follow its own moral convictions in defending its social environment from change it opposes. I shall consider these two arguments in turn, but the second at greater length.

7. Report of the Committee on Homosexual Offenses and Prostitution, supra note 1, at 9-10, 24.

8. Devlin vii. 
The First Argunent: Society's Right to Protect Itself

The first argument-and the argument which has received by far the major part of the critics' attention-is this: ${ }^{9}$

(1) In a modern society there are a variety of moral principles which some men adopt for their orw guidance and do not attempt to impose upon others. There are also moral standards which the majority places beyond toleration and imposes upon those who dissent. For us, the dictates of particular religion are an example of the former class, and the practice of monogamy an example of the latter. A society cannot survive unless some standards are of the second class, because some moral conformity is essential to its life. Every society has a right to preserve its own existence, and therefore the right to insist on some such conformity.

(2) If society has such a right, then it has the right to use the institutions and sanctions of its criminal law to enforce the right-" "[S]ociety may use the law to preserve morality in the same way it uses it to safeguard anything else if it is essential to its existence."10 Just as society may use its law to prevent treason, it may use it to prevent a corruption of that conformity which ties it together.

(3) But society's right to punish immorality by law should not necessarily be exercised against every sort and on every occasion of immorality-we must recognize the impact and the importance of some restraining principles. There are several of these, but the most important is that there "must be toleration of the maximum individual freedom that is consistent with the integrity of society." 11 These restraining principles, taken together, require that we exercise caution in concluding that a practice is considered profoundly immoral. The law should stay its hand if it detects any uneasiness or half-heartedness or latent toleration in society's condemnation of the practice. But none of these restraining principles apply, and hence society is free to enforce its rights, when public feeling is high, enduring and relentless, when, in Lord Devlin's phrase, it rises to "intolerance, indignation and disgust." 12 Hence the summary conclusion about homosexuality: if it is genuinely regarded as an abominable vice, society's right to eradicate it cannot be denied.

We must guard against a possible, indeed tempting, misconception of this argument. It does not depend upon any assumption that when

9. It is developed chiefly in Devin 7-25.

10. Id. at 11 .

11. Id. at 16.

12. Id. at 17 . 
the vast bulk of a community thinks a practice is immoral they are likely right. What Lord Devlin thinks is at stake, when our public morality is challenged, is the very survival of society, and he believes that society is entitled to preserve itself without vouching for the morality that holds it together.

Is this argument sound? Professor H. L. A. Hart, responding to its ap. pearance at the heart of the Maccabaean lecture, ${ }^{13}$ thought that it rested upon a confused conception of what a society is. If one holds anything like a conventional notion of a society, he said, it is absurd to suggest that every practice the society views as profoundly immoral and disgusting threatens its survival. This is as silly as arguing that society's existence is threatened by the death of one of its members or the birth of another, and Lord Devlin, he reminds us, offers nothing by way of evidence to support any such claim. But if one adopts an artificial definition of a society, such that a society consists of that particular complex of moral ideas and attitudes which its members hap. pen to hold at a particular moment in time, it is intolerable that each such moral status quo should have the right to preserve its precarious existence by force. So, Professor Hart argued, Lord Devlin's argument fails whether a conventional or an artificial sense of "society" is taken.

Lord Devlin replies to Professor Hart in a new and lengthy footnote. After summarizing Hart's criticism he comments, "I do not assert that any deviation from a society's shared morality threatens its existence any more than $I$ assert that any subversive activity threatens its existence. I assert that they are both activities which are capable in their nature of threatening the existence of society so that neither can be put beyond the law." 14 This reply exposes a serious flaw in the architecture of the argument.

It tells us that we must understand the second step of the argument -the crucial claim that society has a right to enforce its public morality by law-as limited to a denial of the proposition that society never has such a right. Lord Devlin apparently understood the Wolfenden Report's statement of a "realm of private morality ... not the law's business" to assert a fixed jurisdictional barrier placing private sexual practices forever beyond the law's scrutiny. His arguments, the new footnote tells us, are designed to show merely that no such constitutional barrier should be raised, because it is possible that the challenge to established morality might be so profound that the very existence

13. H. L. A. HaRt, Law, Liberty and Moraltty 51 (1963).

14. DevLriv 13. 
of a conformity in morals, and hence of the society itself, would be threatened. ${ }^{\text {s5 }}$

We might well remain unconvinced, even of this limited point. We might believe that the danger which any unpopular practice can present to the existence of society is so small that it would be wise policy, a prudent protection of individual liberty from transient hysteria, to raise just this sort of constitutional barrier and forbid periodic reassessments of the risk.

But if we were persuaded to forego this constitutional barrier we would expect the third step in the argument to answer the inevitable next question: Granted that a challenge to deep-seated and genuine public morality may conceivably threaten society's existence, and so must be placed above the threshold of the law's concern, how shall we know when the danger is sufficiently clear and present to justify not merely scrutiny but action? What more is needed beyond the fact of passionate public disapproval to show that we are in the presence of an actual threat?

The rhetoric of the third step makes it seem responsive to this question-there is much talk of "freedom" and "toleration" and even "balancing." But the argument is not responsive, for freedom, toler-

15. This reading had great support in the text even without the new footnote:

"I think, therefore, that it is not possible to set theoretical limits to the power of the State to legislate against immorality. It is not possible to settle in advance exceptions to the general rule or to define inflexibly areas of morality into which the law is in no circumstances to be allowed to enter."

DEvir 12-13.

The arguments presented bear out this construction. They are of the reductio ad absurdum variety, exploiting the possibility that what is immoral an in theory become subversive of society.

"But suppose a quarter or a half of the population got drunk every night, what sort of society would it be? You cannot set a theoretical limit to the number of people who can get drunk before society is entitled to legislate against drunkenness. The same may be said of gambling."

Id. at 14 .

Each example argues that no jurisdictional limit may be drawn, not that every drunk: or every act of gambling threatens society. There is no suggestion that society is entitled actually to make drunkenness or gambling crimes if the practice in fact falls below the level of danger. Indeed Lord Devlin quotes the Royal Commission on Betting, Lotteries, and Gaming to support his example on gambling:

"If we were convinced that whatever the degree of gambling this effect [on the character of the gambler as a member of society] must be harmful we should be inclined to think that it was the duty of the state to restrict gambling to the greatest extent practicable."

(CAm. No. 8190 at para. 159 (1951), quoted in Devin 14).

The implication is that society may scrutinize and be ready to regulate, but should not actually do so until the threat of harm in fact exists. 
ation and balancing turn out to be appropriate only when the public outrage diagnosed at the second step is shown to be overstated, when the fever, that is, turns out to be feigned. When the fever is confirmed, when the intolerance, indignation and disgust are genuine, the principle that calls for "the maximum individual freedom consistent with the integrity of society" no longer applies. But this means that nothing more than passionate public disapproval is necessary after all.

In short, the argument involves an intellectual sleight of hand. At the second step, public outrage is presented as a threshold criterion, merely placing the practice in a category which the law is not forbidden to regulate. But offstage, somewhere in the transition to the third step, this threshold criterion becomes itself a dispositive affirmative reason for action, so that when it is clearly met the law may proceed without more. The power of this manoeuvre is proved by the passage on homosexuality. Lord Devlin concludes that if our society hates homosexuality enough it is justified in outlawing it, and forcing human beings to choose between the miseries of frustration and persecution, because of the danger the practice presents to society's existence. He manages this conclusion without offering evidence that homosexuality presents any danger at all to society's existence, beyond the naked claim that all "deviations from a society's shared morality . . . are capable in their nature of threatening the existence of society" and so "cannot be put beyond the law."16

The Second Argument: Society's Right to Follow its own Lichts

We are therefore justified in setting aside the first argument and turning to the second. My reconstruction includes making a great deal explicit which I believe implicit, and so involves some risk of distortion, but I take the second argument to be this: ${ }^{17}$

(1) If those who have homosexual desires freely indulged them, our social environment would change. What the changes would be cannot be calculated with any precision, but it is plausible to suppose, for example, that the position of the family, as the assumed and natural institution around which the educational, economic and recreational arrangements of men center, would be undermined, and the further ramifications of that would be great. We are too sophisticated to suppose that the effects of an increase in homosexuality would be confined to those who participate in the practice alone, just as we are too sophisticated to suppose that prices and wages affect only those who

16. Devlin 13, n.l.

17. Most of the argument appears in Devis chapters V, VI and VII. Sec also an article published after the book: Law and Morality, 1 Manirons L.S.J. 243 (1964/65). 
negotiate them. The environment in which we and our children must live is determined, among other things, by patterns and relationships formed privately by others than ourselves.

(2) This in itself does not give society the right to prohibit homosexual practices. We cannot conserve every custom we like by jailing those who do not want to preserve it. But it means that our legislators must inevitably decide some moral issues. They must decide whether the institutions which seem threatened are sufficiently valuable to protect at the cost of human freedom. And they must decide whether the practices which threaten that institution are immoral, for if they are then the freedom of an individual to pursue them counts for less. We do not need so strong a justification, in terms of the social importance of the institutions being protected, if we are confident that no one has a moral right to do what we want to prohibit. We need less of a case, that is, to abridge someone's freedom to lie, cheat or drive recklessly, than his freedom to choose his own jobs or to price his own goods. This does not claim that immorality is sufficient to make conduct criminal; it argues, rather, that on occasion it is necessary.

(3) But how shall a legislator decide whether homosexual acts are immoral? Science can give no answer, and a legislator can no longer properly turn to organized religion. If it happens, however, that the vast bulk of the community is agreed upon an answer, even though a small minority of educated men may dissent, the legislator has a duty to act on the consensus. He has such a duty for two closely connected reasons: (a) In the last analysis the decision must rest on some article of moral faith, and in a democracy this sort of issue, above all others, must be settled in accordance with democratic principles. (b) It is, after all, the community which acts when the threats and sanctions of the criminal law are brought to bear. The community must take the moral responsibility, and it must therefore act on its own lights-that is, on the moral faith of its members.

This, as I understand it, is Lord Devlin's second argument. It is complex, and almost every component invites analysis and challenge. Some readers will dissent from its central assumption, that a change in social institutions is the sort of harm a society is entitled to protect itself against. Others who do not take this strong position (perhaps because they approve of laws which are designed to protect economic institutions) will nevertheless feel that society is not entitled to act, however immoral the practice, unless the threatened harm to an institution is demonstrable and imminent rather than speculative. Still others will challenge the thesis that the morality or immorality of an act ought even to count in determining whether to make it criminal 
(though they would no doubt admit that it does count under present practice), and others still will argue that even in a democracy legislators have the duty to decide moral questions for themselves, and must not refer such issues to the community at large. I do not propose to argue now for or against any of these positions. I want instead to consider whether Lord Devlin's conclusions are valid on his own terms, or the assumption, that is, that society does have a right to protect its central and valued social institutions against conduct which the vast bulk of its members disapproves on moral principle.

I shall argue that his conclusions are not valid, even on these terms, because he misunderstands what it is to disapprove on moral principle. I might say a cautionary word about the argument I shall present. It will consist in part of reminders that certain types of moral language (terms like "prejudice" and "moral position," for example) have standard uses in moral argument. My purpose is not to settle issues of political morality by the fiat of a dictionary, but to exhibit what $I$ believe to be mistakes in Lord Devlin's moral sociology. I shall try to show that our conventional moral practices are more complex and more structured than he takes them to be, and that he consequently misunderstands what it means to say that the criminal law should be drawn from public morality. This is a popular and appealing thesis, and it lies near the core not only of Lord Devlin's, but of many other, theories about law and morals. It is crucial that its implications be understood.

\section{The Concept of a Moral Position}

We might start with the fact that terms like "moral position" and "moral conviction" function in our conventional morality as terms of justification and criticism, as well as of description. It is true that we sometimes speak of a group's "morals," or "morality," or "moral beliefs," or "moral positions" or "moral convictions," in what might be called an anthropological sense, meaning to refer to whatever attitudes the group displays about the propriety of human conduct, qualities or goals. We say, in this sense, that the morality of Nazi Germany was based on prejudice, or was irrational. But we also use some of these terms, particularly "moral position" and "moral conviction," in a discriminatory sense, to contrast the positions they describe with prejudices, rationalizations, matters of personal aversion or taste, arbitrary stands, and the like. One use-perhaps the most characteristic useof this discriminatory sense is to offer a limited but important sort of justification for an act, when the moral issues surrounding that act are unclear or in dispute. 
Suppose I tell you that I propose to vote against a man running for a public office of trust because I know him to be a homosexual and because I believe that homosexuality is profoundly immoral. If you disagree that homosexuality is immoral, you may accuse me of being about to cast my vote unfairly, acting on prejudice or out of a personal repugnance which is irrelevant to the moral issue. I might then try to convert you to my position on homosexuality, but if I fail in this I shall still want to convince you of what you and I will both take to be a separate point - that my vote was based upon $a$ moral position, in the discriminatory sense, even though one which differs from yours. I shall want to persuade you of this, because if I do I am entitled to expect that you will alter your opinion of me and of what I am about to do. Your judgment of my character will be different-you might still think me eccentric (or puritanical or unsophisticated) but these are types of character and not faults of character. Your judgment of my act will also be different, in this respect. You will admit that so long as I hold my moral position, I have a moral right to vote against the homosexual, because I have a right (indeed a duty) to vote my own convictions. You would not admit such a right (or duty) if you were still persuaded that I was acting out of a prejudice or a personal taste.

I am entitled to expect that your opinion will change in these ways, because these distinctions are a part of the conventional morality you and I share, and which forms the background for our discussion. They enforce the difference between positions we must respect, although we think them wrong, and positions we need not respect because they offend some ground rule of moral reasoning. A great deal of debate about moral issues (in real life, although not in philosophy texts) consists of arguments that some position falls on one or the other side of this crucial line.

It is this feature of conventional morality that animates Lord Devlin's argument that society has the right to follow its own lights. We must therefore examine that discriminatory concept of a moral position more closely, and we can do so by pursuing our imaginary conversation. What must $I$ do to convince you that my position is a moral position?

(a) I must produce some reasons for it. This is not to say that I have to articulate a moral principle I am following or a general moral theory to which I subscribe. Very few people can do either, and the ability to hold a moral position is not limited to those who can. My reason need not be a principle or theory at all. It must only point out 
some aspect or feature of homosexuality which moves me to regard it as immoral: the fact that the Bible forbids it, for example, or that one who practices homosexuality becomes unfit for marriage and parenthood. Of course, any such reason would presuppose my acceptance of some general principle or theory, but I need not be able to state what it is, or realize that I am relying upon it.

Not every reason I might give will do, however. Some will be excluded by general criteria stipulating sorts of reasons which do not count. We might take note of four of the most important such criteria:

(i) If I tell you that homosexuals are morally inferior because they do not have heterosexual desires, and so are not "real men," you would reject that reason as showing one type of prejudice. Prejudices, in general, are postures of judgment that take into account considerations our conventions exclude. In a structured context, like a trial or a contest, the ground rules exclude all but certain considerations, and a prejudice is a basis of judgment which violates these rules. Our conventions stipulate some ground rules of moral judgment which obtain even apart from such special contexts, the most important of which is that a man must not be held morally inferior on the basis of some physical, racial or other characteristic he cannot help having. Thus a man whose moral judgments about Jews, or Negroes, or Southerners, or women, or effeminate men are based on his belief that any member of these classes automatically deserves less respect, without regard to anything he himself has done, is said to be prejudiced against that group.

(ii) If I base my view about homosexuals on a personal emotional reaction ("they make me sick") you would reject that reason as well. We distinguish moral positions from emotional reactions, not because moral positions are supposed to be unemotional or dispassionatequite the reverse is true-but because the moral position is supposed to justify the emotional reaction, and not vice versa. If a man is unable to produce such reasons, we do not deny the fact of his emotional involvement, which may have important social or political consequences, but we do not take this involvement as demonstrating his moral conviction. Indeed, it is just this sort of position-a severe emotional reaction to a practice or a situation for which one cannot accountthat we tend to describe, in lay terms, as a phobia or an obsession.

(iii) If I base my position on a proposition of fact ("homosexual acts are physically debilitating") which is not only false, but is so implausible that it challenges the minimal standards of evidence and argument I generally accept and impose upon others, then you would 
regard my belief, even though sincere, as a form of rationalization, and disqualify my reason on that ground. (Rationalization is a complex concept, and also includes, as we shall see, the production of reasons which suggest general theories I do not accept.)

(iv) If I can argue for my own position only by citing the beliefs of others ("everyone knows homosexuality is a sin") you will conclude that I am parroting and not relying on a moral conviction of my own. With the possible (though complex) exception of a deity, there is no moral authority to which I can appeal and so automatically make my position a moral one. I must have my own reasons, though of course I may have been taught these reasons by others.

No doubt many readers will disagree with these thumbnail sketches of prejudice, mere emotional reaction, rationalization and parroting. Some may have their own theories of what these are. I want to emphasize now only that these are distinct concepts, whatever the details of the differences might be, and that they have a role in deciding whether to treat another's position as a moral conviction. They are not merely epithets to be pasted on positions re strongly dislike.

(b) Suppose I do produce a reason which is not disqualified on one of these (or on similar) grounds. That reason will presuppose some general moral principle or theory, even though I may not be able to state that principle or theory, and do not have it in mind when I speak. If I offer, as my reason, the fact that the Bible forbids homosexual acts, or that homosexual acts make it less likely that the actor will marry and raise children, I suggest that I accept the theory my reason presupposes, and you will not be satisfied that my position is a moral one if you believe that I do not. It may be a question of my sincerity-do $I$ in fact believe that the injunctions of the Bible are morally binding as such, or that all men have a duty to procreate? Sincerity is not, however, the only issue, for consistency is also in point. I may believe that $I$ accept one of these general positions, and be wrong, because my other beliefs, and my own conduct on other occasions, may be inconsistent with it. I may reject certain Biblical injunctions, or I may hold that men have a right to remain bachelors if they please or use contraceptives all their lives.

Of course, my general moral positions may have qualifications and exceptions. The difference between an exception and an inconsistency is that the former can be supported by reasons which presuppose other moral positions I can properly claim to hold. Suppose I condemn all homosexuals on Biblical authority, but not all fornicators. What reason can I offer for the distinction? If I can produce none which supports 
it, I cannot claim to accept the general position about Biblical authority. If I do produce a reason which seems to support the distinction, the same sorts of question may be asked about that reason as were asked about my original reply. What general position does the reason for my exception presuppose? Can I sincerely claim to accept that further general position? Suppose my reason, for example, is that fornication is now very common, and has been sanctioned by custom. Do I really believe that what is immoral becomes moral when it becomes popular? If not, and if I can produce no other reason for the distinction, I cannot claim to accept the general position that what the Bible condemns is immoral. Of course, I may be persuaded, when this is pointed out, to change my views on fornication. But you would be alert to the question of whether this is a genuine change of heart, or only a performance for the sake of the argument.

In principle there is no limit to these ramifications of my original claim, though of course, no actual argument is likely to pursue very many of them.

(c) But do I really have to have a reason to make my position a matter of moral conviction? Most men think that acts which cause unnecessary suffering, or break a serious promise with no excuse, are immoral, and yet they could give no reason for these beliefs. They feel that no reason is necessary, because they take it as axiomatic or self-evident that these are immoral acts. It seems contrary to common sense to deny that a position held in this way can be a moral position.

Yet there is an important difference between believing that one's position is self-evident and just not having a reason for one's position. The former presupposes a positive belief that no further reason is necessary, that the immorality of the act in question does not depend upon its social effects, or its effects on the character of the actor, or its proscription by a deity, or anything else, but follows from the nature of the act itself. The claim that a particular position is axiomatic, in other words, does supply a reason of a special sort, namely that the act is immoral in and of itself, and this special reason, like the others we considered, may be inconsistent with more general theories I hold.

The moral arguments we make presuppose not only moral principles, but also more abstract positions about moral reasoning. In particular, they presuppose positions about what kinds of acts can be immoral in and of themselves. When I criticize your moral opinions, or attempt to justify my own disregard of traditional moral rules I think are silly, I 
will likely proceed by denying that the act in question has any of the several features that can make an act immoral-that it involves no breach of an undertaking or duty, for example, harms no one including the actor, is not proscribed by any organized religion, and is not illegal. I proceed in this way because I assume that the ultimate grounds of immorality are limited to some such small set of very general standards. I may assert this assumption directly or it may emerge from the pattern of my argument. In either event, I will enforce it by calling positions which can claim no support from any of these ultimate standards arbitrary, as I should certainly do if you said that photography was immoral, for instance, or swimming. Even if I cannot articulate this underlying assumption, I shall still apply it, and since the ultimate criteria $I$ recognize are among the most abstract of my moral standards, they will not vary much from those my neighbors recognize and apply. Although many who despise homosexuals are unable to say why, few would claim affirmatively that one needs no reason, for this would make their position, on their own standards, an arbitrary one.

(d) This anatomy of our argument could be continued, but it is already long enough to justify some conclusions. If the issue between us is whether my views on homosexuality amount to a moral position, and hence whether I am entitled to vote against a homosexual on that ground, I cannot settle the issue simply by reporting my feelings. You will want to consider the reasons I can produce to support my belief, and whether my other views and behavior are consistent with the theories these reasons presuppose. You will have, of course, to apply your own understanding, which may differ in detail from mine, of what a prejudice or a rationalization is, for example, and of when one view is inconsistent with another. You and I may end in disagreement over whether my position is a moral one, partly because of such differences in understanding, and partly because one is less likely to recognize these illegitimate grounds in himself than in others.

We must avoid the sceptical fallacy of passing from these facts to the conclusion that there is no such thing as a prejudice or a rationalization or an inconsistency, or that these terms mean merely that the one who uses them strongly dislikes the positions he describes this way. That would be like arguing that because different people have different understandings of what jealousy is, and can in good faith disagree about whether one of them is jealous, there is no such thing as jealousy, and one who says another is jealous merely means he dislikes him very much. 


\section{LoRd Devlin's Morality}

We may now return to Lord Devlin's second argument. He argues that when legislators must decide a moral issue (as by his hypothesis they must when a practice threatens a valued social arrangement), they must follow any consensus of moral position which the community at large has reached, because this is required by the democratic principle, and because a community is entitled to follow its own lights. The argument would have some plausibility if Lord Devlin meant, in speaking of the moral consensus of the community, those positions which are moral positions in the discriminatory sense we have been exploring.

But he means nothing of the sort. His definition of a moral position shows he is using it in what I called the anthropological sense. The ordinary man whose opinions we must enforce, he says, ". . . is not expected to reason about anything and his judgment may be largely a matter of feeling." 18 "If the reasonable man believes," he adds, "that a practice is immoral and believes also-no matter whether the belief is right or wrong, so be it that it is honest and dispassionate-that no right-minded member of his society could think otherwise, then for the purpose of the law it is immoral."10 Elsewhere he quotes with approval Dean Rostow's attribution to him of the view that "the comtion, of reason and feeling, of experience and prejudice." ${ }^{20}$ His sense of what a moral conviction is emerges most clearly of all from the famous remark about homosexuals. If the ordinary man regards homosexuality "as a vice so abominable that its mere presence is an offence," 21 this demonstrates for him that the ordinary man's feelings about homosexuals are a matter of moral conviction. ${ }^{22}$

His conclusions fail because they depend upon using "moral position" in this anthropological sense. Even if it is true that most men think homosexuality an abominable vice and cannot tolerate its presence, it remains possible that this common opinion is a compound of

18. DEvLIN 15.

19. Id. at $22-23$.

20. Rostow, The Enforcement of Morals, 1960 CAMB. L.J. 174, 197; reprinted in E. V. Rostow, The Sovereign Prerogative 45, 78 (1962). Quoted in Devlin 95.

21. Id. at 17 .

22. In the preface (Id, at viii) Lord Devlin acknowledges that the language of the original lecture might have placed "too much emphasis on feeling and too little on rea. son," and he states that the legislator is entitled to disregard "irrational" beliefs. He gives as an example of the latter the belief that homosexuality causes carthquakcs, and asserts that the exclusion of irrationality "is usually an easy and comparatively unim. portant process." I think it fair to conclude that this is all Lord Devlin would allow him to exclude. If I am wrong, and Lord Devlin would ask him to exclude prejudices, per. sonal aversions, arbitrary stands and the rest as well, he should have said so, and attempted to work some of these distinctions out. If he had, his conclusions would have been different and would no doubt have met with a different reaction. 
prejudice (resting on the assumption that homosexuals are morally inferior creatures because they are effeminate), rationalization (based on assumptions of fact so unsupported that they challenge the community's own standards of rationality), and personal aversion (representing no conviction but merely blind hate rising from unacknowledged self-suspicion). It remains possible that the ordinary man could produce no reason for his view, but would simply parrot his neighbor who in turn parrots him, or that he would produce a reason which presupposes a general moral position he could not sincerely or consistently claim to hold. If so, the principles of democracy we follow do not call for the enforcement of the consensus, for the belief that prejudices, personal aversions and rationalizations do not justify restricting another's freedom itself occupies a critical and fundamental position in our popular morality. Nor would the bulk of the community then be entitled to follow its own lights, for the community does not extend that privilege to one who acts on the basis of prejudice, rationalization, or personal aversion. Indeed, the distinction between these and moral convictions, in the discriminatory sense, exists largely to mark off the former as the sort of positions one is not entitled to pursue.

A conscientious legislator who is told a moral consensus exists must test the credentials of that consensus. He cannot, of course, examine the beliefs or behavior of individual citizens; he cannot hold hearings on the Clapham omnibus. That is not the point.

The claim that a moral consensus exists is not itself based on a poll. It is based on an appeal to the legislator's sense of how his community reacts to some disfavored practice. But this same sense includes an awareness of the grounds on which that reaction is generally supported. If there has been a public debate involving the editorial columons, speeches of his colleagues, the testimony of interested groups, and his own correspondence, these will sharpen his awareness of what arguments and positions are in the field. He must sift these arguments and positions, trying to determine which are prejudices or rationalizations, which presuppose general principles or theories vast parts of the population could not be supposed to accept, and so on. It may be that when he has finished this process of reflection he will find that the claim of a moral consensus has not been made out. In the case of homosexuality, I expect, it would not be, and that is what makes Lord Devlin's undiscriminating hypothetical so serious a misstatement. What is shocking and wrong is not his idea that the community's morality counts, but his idea of what counts as the community's morality.

Of course the legislator must apply these tests for himself. If he 
shares the popular views he is less likely to find them wanting, though if he is self-critical the exercise may convert him. His answer, in any event, will depend upon his own understanding of what our shared morality requires. That is inevitable, for whatever criteria we urge him to apply, he can apply them only as he understands them.

A legislator who proceeds in this way, who refuses to take popular indignation, intolerance and disgust as the moral conviction of his community, is not guilty of moral elitism. $\mathrm{He}$ is not simply setting his own educated views against those of a vast public which rejects them. He is doing his best to enforce a distinct, and fundamentally important, part of his community's morality, a consensus more essential to society's existence in the form we know it than the opinion Lord Devlin bids him follow.

No legislator can afford to ignore the public's outrage. It is a fact he must reckon with. It will set the boundries of what is politically feasible, and it will determine his strategies of persuasion and enforcement within these boundries. But we must not confuse strategy with justice, nor facts of political life with principles of political morality. Lord Devlin understands these distinctions, but his arguments will appeal most, I am afraid, to those who do not.

\section{POSTSCRIPT ON PORNOGRAPHY}

I have been discussing homosexuality because that is Lord Devlin's example. I should like to say a word about pornography, if only because it is, for the time being, more in the American legal headlines than homosexuality. This current attention is due to the Supreme Court's decisions and opinions in three recent cases: Ginzburg, Mishkin and Fanny Hill. ${ }^{23}$ In two of these, convictions (and jail sentences) for the distribution of pornography were upheld, and in the third, while the Court reversed a state ban on an allegedly obscene novel, three justices dissented.

Two of the cases involved review of state procedures for constitutionality, and the third the interpretation and application of a federal statute. The Court therefore had to pass on the constitutional question of how far a state or the nation may legally restrict the publication of erotic literature, and on questions of statutory construction. But each decision nevertheless raises issues of political principle of the sort we have been considering.

A majority of the Court adheres to the constitutional test laid down

23. Supra note 2. 
some years ago in Roth. ${ }^{24}$ As that test now stands, a book is obscene, and as such not protected by the first amendment, if: "(a) the dominant theme of the material taken as a whole appeals to a prurient interest in sex; (b) the material is patently offensive because it affronts contemporary community standards relating to the description or representation of sexual matters; and (c) the material is utterly without redeeming social value." 25 We might put the question of political principle this way: What gives the federal government, or any state, the moral right to prohibit the publication of books which are obscene under the Roth test?

Justice Brennan's opinion in Mishkin floated one answer: erotic literature, he said, incites some readers to crime. If this is true, if in a significant number of such cases the same readers would not have been incited to the same crime by other stimuli, and if the problem cannot effectively be handled in other ways, this might give society a warrant to ban these books. But these are at least speculative hypotheses, and in any event they are not pertinent to a case like Ginzburg, in which the Court based its decision not on the obscene character of the publications themselves, but on the fact that they were presented to the public as salacious rather than enlightening. Can any other justification be given for the prohibition of obscene books?

An argument like Lord Devlin's second argument can be constructed, and many of those who feel society is entitled to ban pornography are in fact moved by some such argument. It might take this form:

(I) If we permit obscene books freely to be sold, to be delivered as it were with the morning milk, the whole tone of the community will eventually change. That which is now thought filthy and vulgar in speech and dress, and in public behavior, will become acceptable. A public which could enjoy pornography legally would soon settle for nothing very much tamer, and all forms of popular culture would inevitably move closer to the salacious. We have seen these forces at work already-the same relaxations in our legal attitudes which enabled books like Tropic of Cancer to be published have already had an effect on what we find in movies and magazines, on beaches and on the city streets. Perhaps we must pay that price for what many critics plausibly consider works of art, but we need not pay what would be a far greater price for trash-mass-manufactured for profit only.

24. Roth v. United States, 354 U.S. 476 (1957).

25. Memoirs v. Massachusetts (Fanny Hill), 383 U.S. 413,418 (1966). 
(2) It is not a sufficient answer to say that social practices will not change unless the majority willingly participates in the change. Social corruption works through media and forces quite beyond the control of the mass of the people, indeed quite beyond the control of any con. scious design at all. Of course, pornography attracts while it repels, and at some point in the deterioration of community standards the majority will not object to further deterioration, but that is a mark of the corruption's success, not proof that there has been no corrup tion. It is precisely that possibility which makes it imperative that we enforce our standards while we still have them. This is an example -it is not the only one-of our wishing the law to protect us from ourselves.

(3) Banning pornography abridges the freedom of authors, publishers and would-be readers. But if what they want to do is immoral, we are entitled to protect ourselves at that cost. Thus we are presented with a moral issue: does one have a moral right to publish or to read "hard-core" pornography which can claim no value or virtue beyond its erotic effect? This moral issue should not be solved by fiat, nor by self-appointed ethical tutors, but by submission to the public. The public at present believes that hard-core pornography is immoral, that those who produce it are panderers, and that the protection of the community's sexual and related mores is sufficiently important to justify restricting their freedom.

But surely it is crucial to this argument, whatever else one might think of it, that the consensus described in the last sentence be a consensus of moral conviction. If it should turn out that the ordinary man's dislike of pornographers is a matter of taste, or an arbitrary stand, the argument would fail because these are not satisfactory reasons for abridging freedom.

It will strike many readers as paradoxical even to raise the question whether the average man's views on pornography are moral convictions. For most people the heart of morality is a sexual code, and if the ordinary man's views on fornication, adultery, sadism, exhibitionism and the other staples of pornography are not moral positions, it is hard to imagine any beliefs he is likely to have that are. But writing and reading about these adventures is not the same as performing in them, and one may be able to give reasons for condemning the practices (that they cause pain, or are sacrilegious, or insulting, or cause public annoyance) which do not extend to producing or savoring fantasies about them.

Those who claim a consensus of moral conviction on pornography 
must provide evidence that this exists. They must provide moral reasons or arguments which the average member of society might sincerely and consistently advance in the manner we have been describing. Perhaps this can be done, but it is no substitute simply to report that the ordinary man-within or without the jury box-turns his thumb down on the whole business. 


\section{THE YALE LAW JOURNAL}

\begin{tabular}{lll}
\hline Volume 75 & MAY 1966 & NUMBer 6 \\
\hline
\end{tabular}

Peter L. ZinRoth

Editor-in-Chief

E. EDWard Bruce

Cameron F. Macrae, iII

BENNo C. SCHMTt, JR.

LARRY G. SIMION

Note \& Comment

Editors

\author{
BETSY LEVIN \\ Topics Editor \\ Raymond C. Clevenger, III \\ Mark $\Lambda$. Walker \\ Article \& Book \\ Review Editors
}

BRUCE ACKERMAN
JOHN R. ADLER
LEONARD BECKER
STEPHEN BOMSE
CHARLES N. BURGER
LEONARD CHAZEN
THOMAS CHILDERS
BARRY CRAIG
WALTER E. DELLINGER, III
ARDEN DOSS, JR.
W. LEE H. DUNHAM
VIRGINIA B. EISENSTEIN
JOHN EVANS
DAVID GERBER
GREGORY C. GLYNN
RICHARD GOODYEAR
H. JEFF GREENFIEID
CHARLES H. HERZ
DAVID HESS

BRUCE ACKERMAN

JOHN R. ADLER

LEONARD BECKER

STEPHEN BOMSE

Charles N. Burger

LeONARd Chazen

Thomas ChILDERS

Barry Craig

WALTER E. DELlinger, III

W. LeE H. DunhaMr

VIRGINIA B. EISENSTEIN

JoHN Evans

DAVID GERBER

GrEgoRY C. GLYNN

Charles H. Herz

DAVid Hess
Dennis E. Curtis

Managing Editor

B. Boyd Hight, JR. ALAN C. HOOKER

C. STEPHEN HOWARD

William Iverson

Georce A. Johnson

GEORGE L. JuROW

Lindsey C. Y. KiANG

HowaRD A. KNIGHT

Simon Lazarus, III

RONALD F. LIPP

PHILIP LOCHNER

RICHARD MARKOVITS

Victor Marrero

Alan R. McFarLand, JR

Frederick B. Miclane

THEODORE MILLER

Michael MUUKaSEy

JoHN E. NATHAN

JOSEPH N. ONEK
HAMILTON OSBORNe, JR. Donaldoson C. PILlsnury Charles A. Pulaski, Jr. LEONARD M. ROSS ERIC Schinappen Philip Gordon Schrac John Schulz Alan D. Sistrsky Allan G. Sperling Leonard P. StrickMan ROBERT TANNER David F. Tillotson Michael S. Wald

R. ROBERT F. WALkER SILAS WASSERSTROM JEFFrEY WOOD HENRY WOODWARD Matthew Zwerling
Arthur D. Hellaman Business Manager

\section{Olive Butterfield Business Secretary}

\section{CONTRIBUTORS TO THIS ISSUE}

J. SkElly Wright. Ph.B. 1931, LL.B. 1934, Loyola University of the South. Abraham D. SofaEr. A.B. 1962, Yeshiva College; LL.B. 1965, Ncw York University.

Ronald Dworkin. B.A. 1953, Harvard University; B.A. 1955, Oxford University; LL.B. 1957, Harvard University.

William Huse Dunham, JR. B.A. 1923, Ph.D. 1929, Yale University.

RAlPh E. Giesey. A.B. 1944, M.A. 1947, Wayne State University; Ph.D. 1954, University of California, Berkeley.

H. G. Richardson. M.A., B.Sci., London School of Economics. 